\section{4. 市街地の広場の確保と緑化}

\section{宮崎 辰雄（神戸市助役）}

1. 序

都市計画は，方民の健康の維持增進といら点で，フィ ジカルな面を総合的・網羅的にカバーしていると考えて よい。

都市計画を人体各機関でとにあてはめて䘚現すれば， 以下のとおりである。

1. 頭の健康と都市計画 品間・文化施設等の配置

2. 眼の健康と都市計画 都市美 - 景観 - 建築規制等

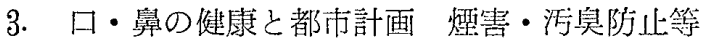

4. 耳の健康と都方計画 騒音防止・遮断緑地の設定 等

5. 体の健康と都市計画 保伥所 - 病院 - 冷暖房 - 温 水道・公瞦・緑地・ゴルフ 場等

6. 脚の倠康と都市計画 遊歩道・緑道・マラソンコ 一ス等

以上の如く分類できると思うが，中でも眼・日・舁・ 体の面にもっとも関連の澡い都市の広場の確保と緑化問 題にしばって論ずる。

2. 広場の確保及び緑化問題と健䐂

健康の維特增進と都市計画における広場の碓保及び緑 化問題とは，切り離すととはできない。

1）日本の都市では公園・緑地が不足している。 神闩市は六大都市中最高の数字 $\left(2,700 \mathrm{~km}^{2}\right)$ を示して

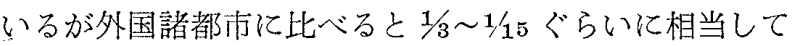
いる。

2）世論調查からも知られる緑地に対する市民の関心 度。

(「)「都市開発に関する市民の世論調查」1963年，神 豆甫。

（1）「文化度調查」1965年，大都方総合企画事務主管 者会議。

以上，最近における2つの調查からも子供の括び場， 公瞏緑地の必要度が高い比率を示している。

3. 広場の碓保之緑化についての若干の提案

市民の高い要求にもかかわらず，現実には，容易に公 喟・緑地面積を急増できない。それは用地確保の困難 性，財源不足等が挙げられる。そこで，比較的実現可能 性をもつ方法として，2～3の提案を試みたい。

1）学校公園の設定

学校管理上，いろいろな問題は存するが，校庭，プー
ルの開放による公国的利用である（花山小学校，五位 の池小学校)。小学校のみに止まらず，幻稚園，中学校， 高校，特然学校にも及ぼすととになり，約 $1,174,000 \mathrm{~m}^{2}$ （35万坪）の広場の確保と緑化が図られる。

とれは，神闻市の場合，既設都市公園面積の $33 \%$ にな る。

2）其同緑地・付属緑地の活用

必ずしも，公的機関の所有地のみの線化でなくともよ い。大規模な境内学もつ神社，仏閣（神而市の場合，2， $500 \mathrm{~m}^{2}$ 以上のもの30ケ所）や病院，団地等のオープン・ スペース，並术帯，街園，花壇，浄水場，眝水場等の空 間等開放して利用すべきであるし，近時，市街地改造に 伴なってビルの屋上庭園化む見逃し難い。

上記の神社，仏閣の数地だけでも近隣公篦面積の $8 \%$ (約200, $\left.000 \mathrm{~m}^{2}\right)$ が生れる。

3）市街地外へ移転した工場跡此の線化利用 アンケート調䍒によれば，現在地から工場を移転した いと肴望するもの約 $20 \%$ もるが，その性の60\%は汸 街地外移転を考学ている。乙れらを行政指導の下 に移転（企業団地など）させ，その䟿地をうまく緑 化するととによって，約 30 万位の緑地面積が捻出でき る。

4）遮断緑地の創設について

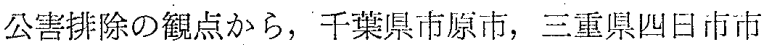
などで，かなり大がかりな計画と取り組み，遮断緑地の 設定を考えているが，本市でもマスタープランにより， 臨海工業地域と住居商業混合地域，又は住居地域との間 そ，東西滯状に遮断緑地計画をもっている。今後具体化 させたい。

また，市街地の無制限なスプロール防止のためにも遮 断緑地（グリーン・ベルト）が必要であるが，その手段 としてゴルフ場の設置と維持を考えるととも一つの方法 である。

5）緑化の推進について

都市をどんどん緑化させ，住民の健康に資することに ついては誰导異存はない。緑の中の生活，潤いのある生 活のよさについて，今少し P Rすることに努めるととも

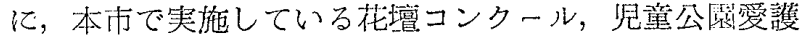
会の育成等も重要な事業である。また，各行事などで出 される記念品には，植木の種子や苗木を壮すようにする など緑化を促進すべきであろう。

4. 結

都市計画はいろいろの面で健水管理・その増進に重大 な役剽を果しつつある。 
その中で，市民の最も要望の高い，しかも日本の都市 で最も遅れ気味である広場の確保と緑化の問題について 言及した。

以上の問題点（提案）で解決され，実現されることに より，本市では全市街地面積の約 $30 \%$ が広場乃至緑地と して確保されるのではないかと考える。

そのような考え方で, 都市の広場の稚保・緑化と都市 計画の関連性を考元いる。

\section{5. 生活様式を考慮した都市計画}

西山 卯三（京都大学工学部建築学教室）

かって，産業革命によって人口の都市集中がすすみ， 労衝者の蝟集するスラム地区が生まれ，都市環境が悪化 して伝染病がまんえんし, 風致も低下するといった時代 に「都市は人間の墓場」であるといわれたととがあっ た。19世紀的都市悪は現在著しく改善されたが，依然と して「都市覀」は消えさらず，最近のわが国の現状をみ ると，都市の生活環境の悪化は目をおおうものがある。 しかも，わが国はもちろん，人類社会全体の「都市化」 は今後ますます激化するものと予想されている。

問題を人間の健康といった点に限っても, 都市化によ る健康条件の悪化はたれの目にも明らかである。しか し、私が,特に注意を喚起したいのは，たれもがきずいて いる大気の污染，騒音，その他いわゆる公害などとよば れている生活環境の悪化，都市化による建てずまり，日 照, 採光, 通風等の条件の悪化, 緑の不足といったとと のほかに，ての都市化の進行の中でかわって行く我々 の生活様式がもたらしている色々な条件の変化である。 かって人間がモグラかアリのように地下道を大群をなし て移動したり，あるいは白アリのように終日人工化され たオフィスビルの中で暮すといったととを人は予想した であろうか。しかし，現害はいまその様なととが日常一 般化し，数十万の人々は身心をすりへらす通勤「学働」 と共に毎日ての生活を「平気」でくりか光している。と てろが，乙のような都市的生活様式は，奏に決して唯一 の残された道，すなわち，必然の生活様式ではなくて， 我々がせんたくしうる沢山の生活様式の中の只一つであ るという事，そして，それを決定するものが都市計画で あるという事一てれが，ててで確然と万人に認証され ねばならない問題なのである。

現在, 進行している現実のてのような都市的生活様式 は，実は「都市環境」あるいは「都市空間」というもの をつくるさまざまの要素, 個人や企業がそれぞれバラバ ラに都市集積の利を最大限に内郭化し，不経消に外郭化
するという形で，各自が最大の利潤を追求するという活 動の結果, うみ出された都市の「自然成長」の結果であ る。ての自然成長のもたらす嫳害を一部除去して, 都市 といら全体像の観点からいく分でも，乙のましい形の生 活空間を得させていこうとするのが「都市計画」なので ある。しかし，その「都市計画」をささえている力は実はと の都市の自然成埐をうみ出している現在の社会体制であ り，その体制は，現在果して今の都市を，またこて何十 年の間におてるであろう, 全国的な都市化の動きに対し て，とのままに制禦をなしうる能力をもつかどうかにつ いてはきわめて疑問の点が多い。例光ば，あらゆる「都 市計画」の大きな障害としてあらわれてくる「土地問 題」の解決などが，ての能力を判定するーつのメドでは ないかと思われるが，今のとてろ我々を安心させる徴候 はみ出せない。

それはさておいて，将来の全国土的都市化の展望をふ まえて, 現在の「都市計面」の体制は, 日本人の健康保 全にきわめて微力な影響力しかもっていない。ての体制 の強化は必要であるが，単に制度のみでなく，どのよう な都市像，国土像をわれわれはもつべきか（それによっ て乎段，体制も変えられていかねばならぬが）について の展望を国民的に明らかにしていくととが必要である。 その展望からふりか党って我々の都市がえらんでいる都 市化の道がどのような危険をはらんでいるかを明らか亿 することが，一つの重要な仕事であると思う。つまり， 都市計画における基本問題の一つとして，都市化によっ ておてる生活構造の将来の変化をいかに展望すべきかと いう問題である。

\section{6. 都市保健䍃画の前提と目標}

\section{関 悌四郎（大阪大学医学部公衆街生学教室）}

都市計画と保健活動

都市計画と保健活動とは，初期の段階では，手をとり あって出発した。上下水道の設置や労働者住宅の対策な ぞ，乙れらはわが国においても，英国などにおける問題 の発生と対策とのあとを追って，社会的にとりあげられ た。

その後も，いくつかの面では都市計画と保健活動との かかわりあいは，たもたれた。たとえば，大気や水の污 染, 騒音などに対しては公采衛生学の側から調查がおて な放れ，資料の提出がなされた。しかし，その資料にも とずく対策が都市計画の中で実現されるという例はとぼ しかった。保健のための政策順位も低いるのであった が，都市計画の政策順位も低い，というよりは問題!さ 